\title{
Managing the current and future supply of ecosystem services in the Hungarian and Romanian Tisza River Basin
}

\author{
Katalin Petz $\cdot$ Elena L. Minca $\cdot$ Saskia E. Werners • \\ Rik Leemans
}

Received: 7 March 2011 / Accepted: 17 January 2012/Published online: 1 February 2012

(C) The Author(s) 2012. This article is published with open access at Springerlink.com

\begin{abstract}
Ecosystem services that sustain human wellbeing depend on the continued functioning of ecosystems, proper management and supporting institutions. However, the interaction between these factors and ecosystem services is poorly understood. Therefore, we assessed how ecosystem services are represented in policy measures, recognized by local population and affected by weather extremes. We studied the Hungarian and Romanian parts of the flood-exposed Tisza River Basin, where all these factors are relevant for regional land and water management. Our qualitative assessment shows that, although the two regions share similar environmental conditions, the different social and institutional settings of the two countries cause a divergence in ecosystem services. Locally produced provisioning services are better recognized in Romania, while regulating (particularly water-regulation) and cultural services are better recognized in Hungary. Food supply is most affected by climate-related weather extremes and most strongly controlled by policy measures in both countries. However, especially in Romania, policy measures support medicinal and genetic resources, and some regulating (e.g. pest regulation) and cultural services, only weakly or indirectly. We conclude that the analysis of ecosystem services in relation to climate-related weather
\end{abstract}

K. Petz $(\bowtie) \cdot$ E. L. Minca $\cdot$ R. Leemans

Environmental Systems Analysis Group, Wageningen

University, PO Box 47, 6700 AA Wageningen, The Netherlands

e-mail: katalin.petz@wur.nl; katalin.petz@gmail.com

E. L. Minca

Nektarina Non Profit, Buconjiceva 4, 10000 Zagreb, Croatia

S. E. Werners

Earth Systems Science - Climate Change Group,

Wageningen University, PO Box 47,

6700 AA Wageningen, The Netherlands extremes, policy measures and people's recognition can contribute to a better management of the Tisza River Basin. We suggest that a better incorporation of ecosystem services in policy and management strategies could enhance and diversify the ecosystem service supply. A further quantification of ecosystem services can, therefore, provide a base for targeted and integrated planning and improved regional policy making.

Keywords Ecosystem services - Flood management . Environmental change · Tisza River Basin · Hungary · Romania

\section{Introduction}

"The ecosystem service approach is different from other approaches to natural resource management because of the focus on managing natural assets for the values they provide, rather than focusing on the problems that arise from inappropriate natural resource management. It also highlights the interdependence of ecological processes and the need to adopt holistic management strategies..." (Binning et al. 2001)

The increasing number of ecosystem service assessments and valuation studies (De Groot et al. 2010a; Hein 2010; MA 2005) shows the growing awareness of the benefits provided by ecosystems. Ecosystem services can be defined as the contribution of ecosystems to human well-being (De Groot et al. 2010a). To sustain a longerterm supply of ecosystem services, it is essential to integrate them into decision-making (Daily et al. 2009; Folke et al. 2004). However, ecosystem services are often neglected in management and planning (De Groot 2006). In 
many cases, the combined effect of inadequate management and altered natural regimes has degraded the capacity of ecosystems to supply services (Folke et al. 2004).

This study focuses on the Central-Eastern European Tisza River Basin, where the historically shifting land and water management regimes have altered the ecosystems and their services (Bellon 2004). The Tisza River springs in Ukraine and is the longest tributary of the Danube River. Its basin is shared between Ukraine, Serbia, Slovakia, Romania and Hungary. This paper studies only the Hungarian and Romanian parts of the Tisza River Basin. In the second half of the nineteenth century, the Tisza River was straightened and forced into a dyke system to meet the increasing demand for protected cultivated land. This regulation changed the water regime and resulted in more severe and faster floods (Bellon 2004). The regional geographical characteristics together with these anthropogenic factors lead to increased exposure to floods and droughts.

In recent decades, an increasing warming trend with more frequent floods and droughts has been observed in Hungary and Romania (Bihari et al. 2005; Government of Hungary 2007b; Ciulache and Ionac 1995). The exposure to these nationally recognized, climate-related weather extremes (EEA 2007; Hungarian Academy of Science 2006a) is likely to increase with future climate change (Badica 2007; Hungarian Meteorological Service and Eötvös Loránd University 2006). Successful adaptation to these changes depends on the extent to which climate and ecosystem concerns are integrated into planning and on the implementation of land use and water management plans (Werners et al. 2009).

We selected and compared two case study regions in the lower Tisza River Basin: the Hungarian Bereg Region and the Romanian Crişul Negru Plain (Fig. 1). Both regions are located in the vicinity of the river and are partly former floodplains. They comprise grassland, arable land and forests with patches of wetlands. Furthermore, they are both pilot areas for new land and water management plans that aim to reduce water risks, conserve biodiversity and introduce multifunctional land use by re-naturalizing former waterways (Dimache 2007; European INTERREG Neighbourhood Programme of Hungary and Ukraine 2006). Minca et al. (2008) assessed the influence of these land and water management plans on ecosystem services from local peoples' perspectives. They found that the current management regime impaired the natural capacity of ecosystems to provide water regulating services, but that there is potential to capitalize on natural water retention. This paper focuses on the socio-political and climatic factors that support land and water management and influence ecosystem services in the lower Tisza River Basin. We assessed how ecosystem services are represented in policy measures, recognized by people and affected by weather extremes.
Fig. 1 Map of the Tisza River Basin. The squares indicate the two case study regions: Hungarian Bereg Region (upper) along the Tisza River and Romanian Crişul Negru Plain (lower) along the Crişul Negru River being a tributary of the Tisza River. Both areas cover about $100 \mathrm{~km}^{2}$ and are pilot areas for new land and water management plans (Dimache 2007; European INTERREG Neighbourhood Programme of Hungary and Ukraine 2006). Map source: Slovak Hydrometeorological Institute (2003)

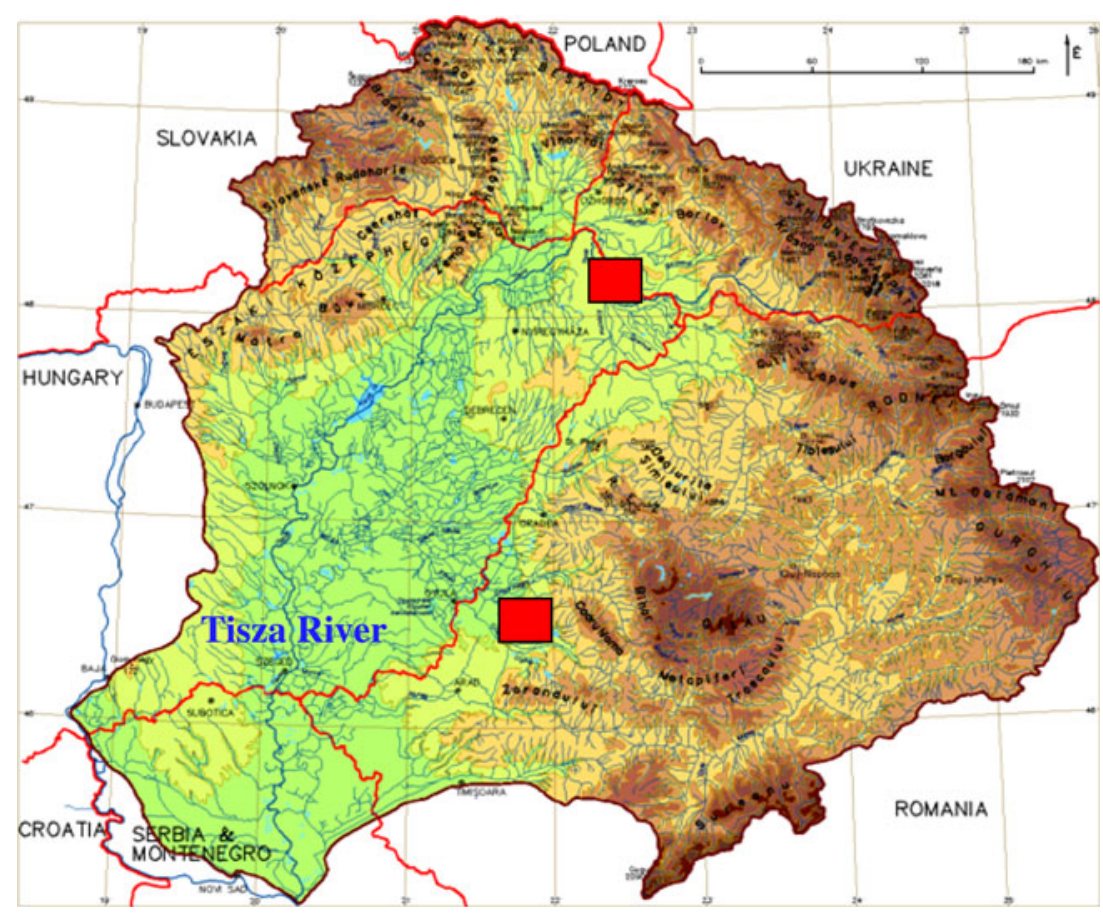




\section{Methods}

We conducted an ecosystem function analysis. Function analysis is a tool to break down complex ecosystem processes into tangible ecological functions and services, and subsequently to analyse all their relationships to different drivers (De Groot 2006). Drivers are natural or humaninduced factors that directly or indirectly cause a change in ecosystem properties (MA 2005). We selected the factors of 'policy measures', 'people's recognition' and 'weather extremes', because they are relevant for the region and its management (Werners et al. 2009). They represent political, social and environmental changes, respectively, and each influences or supports land and water management in the two regions. Policy measures are taken by European, national and regional decision-makers; they generally control ecosystem services indirectly, and they involve different institutional dimensions. The local people, on the contrary, manage ecosystem services directly and thus have a more direct relation to ecosystems services and their supply. They are aware of a wide range of local ecosystem services. We call the perception of ecosystem services by the local people 'recognition'. People's recognition thus shows to what extent which services are important to local people (Minca et al. 2008). Both 'policy measures' and 'people's recognition' give information on the degree to which a service is appreciated and used by society. Stronger support by policy measures and higher recognition can enhance ecosystem services. In turn, the awareness of ecosystem services can improve policy measures and can increase recognition. Climate-related 'weather extremes' relate to environmental factors, such as droughts and floods. These are (partly) caused or enhanced by changing climate (Badica 2007; Hungarian Meteorological Service, Eötvös Loránd University 2006).

The composition, structure and condition of ecosystems determine their capacity to generate services (De Groot et al. 2002). Climate-related weather extremes can alter the dynamics and structure of ecosystems and, therefore, can trigger changes in ecosystem services (Schröter et al. 2005). Droughts and floods may affect ecosystem services negatively. Most land and water management plans also include policy measures to respond to weather extremes and cope with them. Therefore, policy measures, people's recognition and weather extremes all affect the supply of ecosystem services (Fig. 2).

We adopted the comprehensive terminology and classification of ecosystem services from the Millennium Ecosystem Assessment (2005): provisioning services, regulating services, cultural services and supporting services. Supporting services are the basis for the production of all other ecosystem services and often overlap with them (De Groot et al. 2010a). We have, therefore, excluded

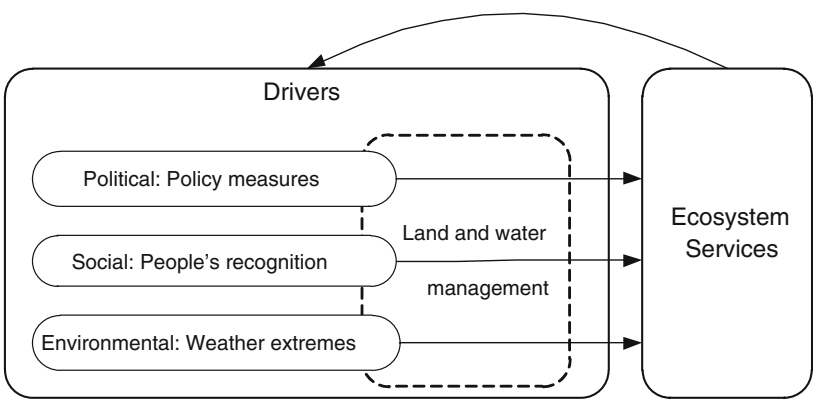

Fig. 2 Schematic overview of the research with the focus on how ecosystem services are represented in policy measures, recognized by people and affected by weather extremes (three horizontal arrows). All three factors are relevant for regional land and water management. The arrows indicate effects

supporting services from our study to avoid double counting. The ecosystem services used in this study include the provision of food, raw materials, genetic and medicinal resources, water regulation, water purification, natural hazard regulation, pest regulation, soil quality regulation, recreation and ecotourism, aesthetic value and cultural value. These ecosystem services were selected because:

- they are likely to change with changing land and water management within a time scale of 20-30 years (e.g. 'spiritual and religious values' and 'air quality regulation' are unlikely to be affected by the factors we considered and were, therefore, omitted);

- they are present and can be measured on a regional (river basin) scale (e.g. 'climate regulation' is more important globally and was, therefore, omitted);

- there is sufficient information available (e.g. the 'nutrient supply' and 'erosion-control' services were omitted due to the lack of available data).

We reviewed scientific literature (e.g. De Groot 2006; De Groot et al. 2010b; Hein et al. 2006; MA 2005; World Resources Institute, United Nations Development Programme, United Nations Environment Programme, World Bank 2000), policy reports (e.g. Jolánkai et al. 2004; Crişuri Water Directorate 2006) and articles specific to the study area (e.g. 'Agro-21' Brochures) to identify indicators that measure different aspects of the selected ecosystem services. These indicators needed to be clearly defined, measurable in qualitative or quantitative terms, achievable with the resources and time available, relevant for the issue and sensitive to changes within policy and management time frames (Niemeijer and de Groot 2008). In some cases several indicators were selected to measure a specific service, whereas in other cases, only one indicator was selected as a measure for several services. For example, land use provides information on both water regulation and food provision. The indicators selected provide information about the biophysical characteristics (e.g. forest area, soil 
Table 1 Examples of indicators used to assess ecosystem services

\begin{tabular}{|c|c|}
\hline Ecosystem services & Indicators \\
\hline \multicolumn{2}{|l|}{ Provisioning services } \\
\hline Food & $\begin{array}{l}\text { Land use type } \\
\text { Crops and fruit harvest } \\
\text { Area under cultivation } \\
\text { Grazing domestic animals } \\
\text { Fish catch } \\
\text { Hunting, game management } \\
\text { Utilization of forest products } \\
\text { (mushrooms, berries, seeds) } \\
\text { Measures supporting food production }\end{array}$ \\
\hline Raw materials & $\begin{array}{l}\text { Land use type } \\
\text { Tree, timber harvest } \\
\text { Reed/sallow harvest } \\
\text { Measures supporting raw material } \\
\text { production }\end{array}$ \\
\hline Medicinal resources & $\begin{array}{l}\text { Medicinal plants collected } \\
\text { Medicinal plants protected } \\
\text { Measures supporting protection or use } \\
\text { of medicinal resources }\end{array}$ \\
\hline Genetic resources & $\begin{array}{l}\text { Regional species } \\
\text { Species and area protection } \\
\text { Measures supporting protection or use } \\
\text { of genetic resources }\end{array}$ \\
\hline \multicolumn{2}{|l|}{ Regulating services } \\
\hline Water regulation & $\begin{array}{l}\text { Land use type } \\
\text { Presence and extent of canals and } \\
\text { sluices } \\
\text { Groundwater level } \\
\text { Genetic soil type } \\
\text { Problem of inland water stagnation or } \\
\text { flood } \\
\text { Measures supporting natural water } \\
\text { retention } \\
\text { Natural water inundation or drought }\end{array}$ \\
\hline Water purification & $\begin{array}{l}\text { Land use type } \\
\text { Concentrations of nitrogen and } \\
\text { phosphorus in the surface water/ } \\
\text { groundwater } \\
\text { Sustainable concentrations of nitrogen } \\
\text { and phosphorus } \\
\text { Plans on wetland creation/protection } \\
\text { Communal sewage treatment by } \\
\text { natural system } \\
\text { Measures supporting natural water } \\
\text { purification and wetland } \\
\text { establishment }\end{array}$ \\
\hline Pest regulation & $\begin{array}{l}\text { Presence and abundance of pests } \\
\text { Presence of pest predators } \\
\text { Crop rotation/monoculture } \\
\text { Natural water inundation or drought } \\
\text { Measures supporting natural pest } \\
\text { control }\end{array}$ \\
\hline
\end{tabular}

Table 1 continued

\begin{tabular}{|c|c|}
\hline Ecosystem services & Indicators \\
\hline \multirow[t]{5}{*}{ Soil quality regulation } & Use of fertilizers \\
\hline & Natural water inundation \\
\hline & $\begin{array}{l}\text { Number of days with flood water } \\
\text { cover }\end{array}$ \\
\hline & Crop rotation/monoculture \\
\hline & Measures focusing on soil productivity \\
\hline \multirow{4}{*}{$\begin{array}{l}\text { Natural hazard regulation } \\
\text { (floods and droughts) }\end{array}$} & Frequency of floods/droughts \\
\hline & Forest covered area \\
\hline & Measures for flood management \\
\hline & $\begin{array}{l}\text { Measures supporting natural water } \\
\text { retention }\end{array}$ \\
\hline \multicolumn{2}{|l|}{ Cultural services } \\
\hline \multirow[t]{3}{*}{ Aesthetic value } & $\begin{array}{l}\text { Diversity of landscape (mosaic land } \\
\text { use, church towers, etc.) }\end{array}$ \\
\hline & Presence of abandoned land \\
\hline & $\begin{array}{l}\text { Measures supporting non-productive } \\
\text { investments and alternative } \\
\text { management methods }\end{array}$ \\
\hline \multirow[t]{7}{*}{ Recreation and ecotourism } & Land use type \\
\hline & Visitors, tourists \\
\hline & Ecopaths/bicycle roads \\
\hline & $\begin{array}{l}\text { Recreational facilities (beach, fishing } \\
\text { places, spa etc.) }\end{array}$ \\
\hline & Area protection \\
\hline & $\begin{array}{l}\text { Presence of fishing/hunting } \\
\text { association/fishing pond }\end{array}$ \\
\hline & $\begin{array}{l}\text { Measures supporting non-productive } \\
\text { investments and alternative } \\
\text { management methods }\end{array}$ \\
\hline \multirow[t]{4}{*}{ Cultural value } & Cultural, historical sites \\
\hline & Regional products \\
\hline & Regional customs/traditions \\
\hline & $\begin{array}{l}\text { Measures supporting traditional } \\
\text { farming or regional products }\end{array}$ \\
\hline
\end{tabular}

type and presence of pest predators) and the management of the area (e.g. crop rotation and protection of species), the relevant sub-services (e.g. fruit and crop as food, and timber and reed as raw material) and/or the human use of services (e.g. crops harvested and medicinal plants collected) (c.f. Table 1). Although these indicators do not fully describe all aspects of ecosystem services, they allow the services to be measured and assessed and they can also link services to policy measures, people's recognition and weather extremes.

By using these indicators, we assessed how the ecosystem services are represented in policy measures, recognized by people and affected by weather extremes. We used both secondary (i.e. literature, policy documents, 
Table 2 A summary of the analysed policy documents at European, national and regional levels

\begin{tabular}{|c|c|c|}
\hline $\begin{array}{l}\text { Policy } \\
\text { level }\end{array}$ & Hungary & Romania \\
\hline European & $\begin{array}{l}\text { Water Framework Directive } \\
\text { Ramsar Convention } \\
\text { Natura } 2000\end{array}$ & \\
\hline \multirow[t]{3}{*}{ National } & $\begin{array}{l}\text { New Hungarian Rural Development Programme* } \\
\text { (Government of Hungary 2007b) }\end{array}$ & $\begin{array}{l}\text { Romanian National Rural } \\
\text { Development Programme* } \\
\text { (Government of Romania 2007a) }\end{array}$ \\
\hline & $\begin{array}{l}\text { Environment and Energy Operational Programme* } \\
\text { (Government of Hungary 2007a) }\end{array}$ & $\begin{array}{l}\text { Sectoral Operational Programme } \\
\text { for Environment* } \\
\text { (Government of Romania 2007c) }\end{array}$ \\
\hline & Policy on National Protected Areas & Policy on National Protected Areas \\
\hline Regional & $\begin{array}{l}\text { North Great Plain Operational Programme* } \\
\text { (Government of Hungary 2007c) }\end{array}$ & $\begin{array}{l}\text { Regional Operational Programme* } \\
\text { (Government of Romania 2007b) }\end{array}$ \\
\hline
\end{tabular}

* Sign refers to period 2007-2013

reports and statistics) and primary (i.e. interview) data sources. Each data source provided information on the indicators and ecosystem services themselves. Literature and policy documents, furthermore, gave insight into policy measures and climate-related weather extremes, whereas interviews gave insight into people's recognition and climate-related weather extremes. We obtained qualitative and quantitative data, both of which were assessed and synthesized qualitatively.

The indicator list served as the backbone for the interviews. Interviews were the main information source to evaluate people's recognition, which was assessed qualitatively. Using the indicator list, we presented examples and asked interviewees which ecosystem services they value or appreciate the most and the least. In this way, we determined the relative importance of all services. The interviewees ranged from scientific experts (e.g. climatologists, ecologists and hydrologists) to regional and local authorities (e.g. water management boards members, mayors and NGO representatives). We conducted 20 interviews in each country. The experts were consulted on land and water management issues, the way local people living in the region perceive and use ecosystem services, and their experiences concerning weather extremes. We used a semi-structured interviewing technique with open questions, such as: 'Which land use type provides most benefits?', 'How does flooding affect the food provisioning?', 'What effect does water management have on the benefits provided by the land?' and 'Do local people collect medicinal plants?' The interviewees and local institutions also provided policy documents (e.g. a flood and drought risk report by the Upper-Tisza Environment and Water Authority) and statistics (e.g. crop yields from the Agrarian Chamber), which we used as additional input for the qualitative ecosystem services assessment. An informal field observation across the study area confirmed and validated the information collected from interviews, for example, the condition of canals/sluices and state of different land uses. This field observation confirmed the data collection and will not be discussed further.

We analysed policy documents to assess whether policy measures include and support ecosystem services. A number of European, national and regional policy documents were selected on the basis of their relevance and analysed for their support of ecosystem services (summarized in Table 2). In each document, the policy target and the number and content of the measures that (could) have an effect on the delivery of ecosystem services were considered. For instance, in the New Hungarian Rural Development Programme (RDP), we selected the agroenvironmental payment, which is devoted to the promotion of environment friendly farming practices with respect to biodiversity preservation, nature, water and soil protection and genetic resources' (Government of Hungary $2007 \mathrm{~b}$ ). The nutrient management suggested in the agroenvironmental payment scheme can improve the soil's physical and chemical attributes and soil water management (Government of Hungary 2007b). It, therefore, enhances the soil quality regulation service. We analysed all measures from the selected policy documents following this approach.

The support and effect of policy measures, people's recognition and weather extremes on the provision of ecosystem services were described and evaluated qualitatively by assessing and synthesizing all the information collected. We illustrate the combined effects of these factors mainly on the food provision service because more information was available about this service than the others. 


\section{Results}

Policy measures

The EU Water Framework Directive (WFD: http://ec.europa. eu/environment/water/water-framework/) advocates the achievement of 'good status' for surface and ground waters together with the protection of aquatic ecology and drinking water resources. Furthermore, the UN Ramsar Convention (www.ramsar.org) aims to conserve wetlands and use them wisely, which is defined as maintaining their ecological character through the implementation of ecosystem approaches. An adequate integration and implementation of both acts could support ecosystems in providing services such as water regulation, water purification and natural hazard regulation. There are twentyeight Ramsar sites in Hungary including the floodplain of the Tisza River. However, there are only five Ramsar sites in Romania, none of which is located in the study region. The Ramsar targets, furthermore, are not mentioned in any of the national, sectorial and regional development programmes in either of the countries.

Hungary intends to achieve the WFD objectives in the frame of its New Hungarian RDP through agro-environmental payments, measures of compensatory payments to less productive areas and compensatory payments for environmentally sound land use in Natura 2000 areas (Government of Hungary 2007b). Romania intends to achieve the WFD objectives in the frame of the Romanian National RDP through agro-environment payments, but does not consider other measures (Government of Romania 2007a). Moreover, in both countries, the sectorial programmes only briefly mention the WFD (Government of Hungary 2007a; Government of Romania 2007c), and the regional programmes fail to include the WFD and Ramsar targets (Government of Hungary 2007c; Government of Romania 2007b).

The Natura 2000 network (http://ec.europa.eu/environment/ nature/natura2000) focuses on the protection of Europe's most valuable and threatened species and habitats through sustainable ecological and economic management. $21 \%$ of the area of Hungary was designated as Natura 2000 sites, which consist of pastures, arable lands and forests (Government of Hungary 2007b). In general, the Natura 2000 network is well incorporated in the New Hungarian RDP and is mentioned in the sectorial programmes, but the network's monitoring still lags behind. Approximately half of the Hungarian study region falls in the Natura 2000 network (Upper-Tisza Environment and Water Authority 2007). Farmers adopted the Natura 2000 guidelines in 2004 and changed to environmentally sound grass mowing methods to protect corncrakes (Crex crex). The compensatory payments for sustainable grassland management were introduced in 2007 (Molnár et al. 2007). Furthermore, the European LIFE-Nature instrument (the EU's financial instrument for environmental projects that contribute to the implementation of the Natura 2000 network, ec.europa.eu/ environment/life/) finances the restoration of formerly drained, but now protected and endangered peat-bogs and wetlands. ${ }^{1}$ The aim is to establish and manage sustainably a network of natural wetland, grassland and forest patches to protect endemic species. Therefore, Natura 2000 policies in the study area can support the functioning of grassland and wetland ecosystems, their biodiversity and their services, such as genetic and medicinal resources, and water- and soil-related regulating services.

Approximately $18 \%$ of the area of Romania was designated as Natura 2000 sites (Government of Romania 2007a; Stancioiu et al. 2010). The Romanian National RDP only indicates a possible inclusion of Natura 2000 into the national policy. However, the lack of financial resources, strategic policies and the designation of areas already protected as Natura 2000 sites might lead to gaps in the network (Groza et al. 2006). Our interviews show that the local representatives are unfamiliar with the Natura 2000 concepts and their consequences. The network is implemented without a thorough field analysis or proper stakeholder consultation, and sites were declared protected although there is no compensation system for owners (Stancioiu et al. 2010). In the Romanian study region, there are two Natura 2000 sites. These are the Crişul Negru, which is essential for the mussel (Unio crassus) population, and Goronişte Forest, which is important for maintaining the protected, but still intensely collected, narcissus (Narcissus spp.) (Government of Romania 2005). Therefore, Natura 2000 policies in the study area support the functioning of forest and riparian ecosystems, their biodiversity and their services. The mussel and daffodil populations, for example, not only have intrinsic biodiversity values but also provide genetic resources, which can be sustained by protecting these species. Species collection, on the other hand, represents a provisioning service (either food or ornamental resource). This illustrates the trade-offs between different ecosystem services. The full implementation and monitoring of Natura 2000 policies could ensure a balance between all services through the sustainable management of these ecosystems.

The most important measure of the national rural development programmes, the agro-environment payment schemes, supports mainly grassland ecosystems, food provision and water- and soil-related regulating services (Government of Hungary 2007b; Government of Romania 2007a). In addition, the Hungarian arable land, orchard and wetland ecosystems and their services are also sustained

\footnotetext{
${ }^{1}$ Project name: Complex Habitat Rehabilitation of the Central Bereg Plain, Northeast Hungary, www.lifebereg.hnp.hu.
} 
through specific measures, which focus on the preservation of genetic resources and on agro-forestry systems by forestenvironmental payments and other non-productive investments (e.g. in aesthetic values and recreation) (Government of Hungary 2007b). The extra measures in Romania support less favoured mountain areas and Natura 2000 payments for forestry lands (Government of Romania 2007a).

The nature protection areas are protected by specific national laws and are mainly owned by the state in both countries (Government of Hungary 2007a; Government of Romania 2007c). In the past, the policy on national protected areas was more conservation oriented and aimed " $t o$ protect and maintain the protected plant and animal species, natural plant communities, the specific scenic features, the landforms..." (www.lifebereg.hnp.hu). However, there is a shift in approach towards restoration and sustainable management as the European targets (such those specified by Natura 2000) are being incorporated. For example, the policy of the Szatmár-Bereg Nature Protection Area in the Hungarian study region aims to restore peat-bogs, wetlands and forests, whereas the protected Goronişte Forest in the Romanian study region maintains forest species and ecosystems.

The sectorial programmes of the Environment and Energy Operational Programme and Sectorial Operational Programme for Environment focus on the conservation of natural habitats (including protected and Natura 2000 areas) and on sustainable water management (Government of Hungary 2007a; Government of Romania 2007c). The only measure to receive a substantial financial share is the 'wise management of waters' (almost 30\% of the overall budget, whereas all other measures are below 5\%) (Government of Hungary 2007a). This measure promotes the use of ecosystems to provide natural flood protection and water retention.

\section{People's recognition}

Local authority representatives and experts (e.g. mayors, NGO representatives and members of agrarian chambers and water boards) provided information about their areas of expertise and their knowledge of the local population. This was used to assess the population's general recognition of ecosystem services in the two case study regions. The interviews showed that food provision is by far the best recognized service: local people value food from arable land (wheat, maize, sunflower, legumes and potatoes) most because it is linked to a major economic activity. The average wheat yield in both regions is $3,500 \mathrm{~kg} / \mathrm{ha}$, whereas the maize is $5,500 \mathrm{~kg} / \mathrm{ha}$ in the Hungarian study region and 4,200 kg/ha in the Romanian. The Hungarian crops are not used locally but sold outside the region, while in Romania most crops are used locally. Yields are highest and most stable along the primary floodplain of the Tisza, thanks to continuous water and nutrient supplies. Grasslands are characterized by extensive animal husbandry providing milk (and meat). Animal husbandry is as important as crop production in the Romanian study region, but it is only marginal in Hungary. The number of grazing animals has declined significantly in the last decades, and milk production serves mainly local needs. Hungarian interviewees also claim that about $30 \%$ of the grassland is abandoned, and its condition is poor. The apples, cherries, plums and nuts grown in orchards are highly recognized in the Hungarian region. Fruit are consumed locally or sold by small local companies as brandy, desiccated fruit, juice and jam. Other land uses are less recognized as food sources: fish from streams, berries and mushrooms from forests (especially porcini-Boletus Edulis) are collected only for personal consumption and in small amounts. The only plant species gathered for trade in Hungary is the elderberry (Sambucus nigra, flowers and fruits). Rose hip (Rosa canina) is collected for local consumption in Romania. The other provisioning services (e.g. raw materials, medicinal resources and genetic resources) are less appreciated and used. Local people seem to have limited knowledge on the benefits of medicinal plants, and only few people collect them. The medicinal plants that occur in the Hungarian area (e.g. German camomile (Matricaria chamomilla), comfrey (Symphytum officinale) and celandine (Chelidonium majus)) are no longer collected. In Romania, people still collect German camomile, St. John's wort (Hypericus perforatum) and hawthorn (Crataegus pentagyna), but only in small amounts. Collection and use of local raw materials is no longer important in the Hungarian region, but people still collect hay, wood, reeds and willow rods in Romania.

Overall, the interviews show that provisioning services are more frequently recognized than regulating and cultural services. The natural water regulation, pest regulation, soil quality regulation and purification capacities of ecosystems are, for example, poorly acknowledged by local people. However, Hungarian experts are aware of the positive effect of regular water inundation and crop rotation on soil productivity and pest control (rodents and gypsy moth (Lymatria Dispar)), while pests are not considered a problem in Romania because of the balanced natural control provided by regular flooding and predators. Interviewees stated that wetlands, natural waterways and canals are important for collecting run-off and inland water and retaining water supplies, thus mitigating the effect of the uneven water distribution. Nevertheless, the condition of the canals is fairly poor, and they are often filled with sediment and are overgrown. Wetlands are either drying out or are characterized by shallow and eutrophic water (overgrown with water chestnut (Trapa natans) and common duckweed (Lemna Minor)), because of the poor 
maintenance and lack of regular water flow. Romanian experts stressed the pollutants carried by the river and the dominance of regulatory engineering measures that lead to high water speeds along the river.

Among the cultural services, recreation and ecotourism are the only ones valued. Local people use the Tisza River in Hungary and the forests of the Crişul Negru Plain in Romania for recreation. In addition, ecotourism is starting to gain in popularity in Hungary, as indicated by a few ecopaths, bicycle roads and fishing ponds. Aside from a few annual cultural events (such as in the Harvest Day and Plum Day in Hungary), the cultural value associated with the landscape has been diminished, and local people are not aware of the cultural and aesthetic value of their land. In Romania, traditions related to sowing and harvesting and the manufacture of buttons made from river shells, which used to be important, are not practised anymore.

In Hungary, local people generally recognize ecosystem services better than in Romania. This was very clear from the interviews. In Romania, only locally produced provisioning services, such as wood, reed, willow rods and to some extend medicinal resources, are appreciated. The regulating and cultural services are less respected than in Hungary, although they are equally present and enjoyed. Hungarian interviewees indicated plum products and wicker baskets as cultural services, whereas in Romania, such products were referred to as provisioning services. In general, local people attribute the highest value to arable lands, which are the main source of food and economic activities, and the lowest value to wetlands, which are often considered non-productive, difficult to access or unpleasant (mosquitoes).

Weather extremes: floods and droughts

Weather extremes, changes in land use and habitat fragmentation represent huge pressures on ecosystems (Hungarian Meteorological Service, Eötvös Loránd University 2006). In the Tisza River Basin, drought occurrences seem to show a more predictable, increasing trend than floods, which follow a more random pattern (Bihari et al. 2005). Floods and droughts have major effects on wetland, arable land and water body ecosystems. All these systems are highly sensitive to water dynamics. Wetland is considered as a 'transition' ecosystem between water bodies and grassland, and even small disturbances in the water supply can turn it into one or the other (Hungarian Academy of Science 2006a, 2007; Hungarian Meteorological Service, Eötvös Loránd University 2006).

The yield of arable land is sensitive to weather extremes. Small variations in water supply can already cause a significant change in agricultural production, and drought can cause yield losses of up to $40 \%$ (Szász 2005; Vermes
2006). Grasslands and orchards can adapt to new, drier conditions better, than arable lands (Benedek 2005; Hungarian Academy of Science 2006a; Hungarian Meteorological Service, Eötvös Loránd University 2006). However, a severe summer drought can induce significant losses in Hungarian fruit production (Vermes 2006) and Romanian livestock production (Chiriac et al. 2005; Vermes 2006). Depending on their species composition, location and management regime (e.g. natural, planted or intensively or extensively managed), large variations in the resilience towards weather extremes may occur in forests (Hungarian Academy of Science 2006a; Hungarian Meteorological Service, Eötvös Loránd University 2006). In general, weather extremes seem to affect the following ecosystems in decreasing order: arable lands, orchards, wetlands and forests.

Local experts pointed out that the less recognized services, such as water and soil quality regulation, are also affected by weather extremes. The warming trend and the more frequent weather extremes have had an overall negative influence on soil productivity (Hungarian Academy of Science 2006a). Another example is the pest regulation service. Droughts, for example, raised the rodent population in the Hungarian study region. In general, extended dry periods are favourable for new agricultural pest species (Benedek 2005), and with climate change, the damage they cause is expected to increase in frequency and intensity (Blujdea 2005). Changing water conditions also affect medicinal resources by influencing the active substances of medicinal plants (Hungarian Academy of Science 2006b).

\section{Combined effect of factors: food provision service}

Among all services, food is the best documented and most valued service. In both countries, food provision is negatively affected by water extremes (which are related to current water management), lower arable soil qualities or poor maintenance and abandonment of grassland. The policy measures of the national RDPs (e.g. agro-environmental payments) primarily target arable land through imposed tillage methods and crop rotation (Government of Hungary 2007b; Government of Romania 2007a). In the policy documents, the food provided by forests (berries, mushrooms, game), water bodies (fish) and wetlands (fish) is not supported. The interviews showed that in Hungary, the production of cereals on arable lands and fruit in orchards are the most recognized service, while in Romania, it is the production of livestock and cereals. Furthermore, some Romanians still rely to some extent on fish, berries and mushrooms as a secondary food source. According to local Hungarian experts, weather extremes can reduce food production by up to $40 \%$. The large 
variations in yields observed are primarily caused by the variability of the water supply (Szász 2005). Although orchards and grasslands are more resistant to weather extremes than arable land, drought may also cause significant losses in fruit production (Vermes 2006). Interviews suggest that drought and floods cause bigger concern and lead to higher cereal and fruit yield losses in Hungary than in Romania.

\section{Discussion}

\section{Policy measures}

Policies influence ecosystems and their services. Liu et al. (2008), for example, highlighted that targeted and effective ecosystem service-focused policies in China can be ecologically and socio-economically beneficial. We investigated the support of ecosystem services in Hungarian and Romanian policies. We found that the concept of ecosystem services is not mentioned in any of the policy documents. Nevertheless, the documents indicate possibilities for enhancing some services through various measures. The Romanian legislation is generally unspecific and not measure-focused. The European policy acts are better integrated into the Hungarian national plans, with more targeted measures and higher budgets. This can be partly explained by the fact that Hungary joined the European Union earlier (2004) than Romania (2007). The national RDPs, which reflect European legislation, mainly support water-related provisioning and regulating services. Cultural services have so far received little attention, but aesthetic values and recreation could possibly be enhanced through non-productive investments (Government of Hungary 2007b).

The shift from conservation to sustainable management in the nature protection areas in Hungary could enable a sustainable use of ecosystem services in the future. The implementation of the sectorial programmes could affect water regulation and natural hazard regulation services positively, though this is more likely in Hungary than in Romania. However, the traditional trust in hard, structural water infrastructure and the small financial share of the other measures may form a barrier to achieve this.

The ecosystem service provision might be impaired by the exclusion of European and national policy measures at the regional level. Our literature review showed that policy measures are starting to include, albeit in very vague formulations, some measures that may help to enhance ecosystem services. However, we recognize that there are also other factors that may influence ecosystem services supply. Our findings can be used to further promote policy measures that have a positive influence on ecosystem services (e.g. support of water-related provisioning and regulating services by agro-environmental payments) as well as to better include poorly addressed services (e.g. non-water related regulating and cultural services).

\section{People's recognition}

A better knowledge of the services that are important for local people can improve decision-making (Sheil et al. 2006). We introduced the ecosystem service approach to local people and assessed how they perceive services. The interviewees' responses reflect a combination of their expertise and perception, and their knowledge of local people's perceptions of the importance of ecosystem services. In addition, our results also reflect how effectively the indicators and our description could represent the ecosystem services themselves. Some services, such as food provision and recreation, could more easily be described and represented by tangible specific indicators than the more abstract services, such as natural hazard regulation and aesthetic value. Therefore, the selection of services, indicator list and interviewees also can influence the results. An alternative method of obtaining additional information would be the use of questionnaires, which allows to consult many more people and, therefore, could provide a more comprehensive picture. However, we believe that our interviews provide a general overview of the recognition of ecosystem services in the two study regions.

Our analysis shows that local people's recognition is an important aspect of ecosystem service analysis. Information on people's specific relationship with their surroundings, for example, can be used to establish better, locationspecific management plans. Ecosystem service assessments applying a similar, interview-based methodology underline that local people's perceptions and experts' knowledge can be beneficial for local policy and management (c.f. Burkhard et al. 2009; Kosoy et al. 2007; Sheil et al. 2006).

Weather extremes: floods and droughts

The national policies on climate change and weather extremes strongly stress the vulnerability of different economic sectors (Hungarian Academy of Science 2006a; Ministry of Water and Environment 2008). Our results show that the relationship between weather extremes and ecosystem services is complex, and that increased weather extremes could lead to the impairment of services. There is more information available about the influence of weather extremes on certain services in Hungary (c.f. the 'Agro-21' and 'Klíma-21' Brochures and Hungarian National Climate Strategy; www.vahavahalozat.hu) than in Romania. In general, the local scientific literature touches upon flood 
and drought trends, but much less upon their influence on ecosystem services. This shows the need for more focused research on the relationship between weather extremes and ecosystem services. A better understanding of these interactions could help to adapt land and water management to changing climatic conditions. Hungary's 'Climate change and biodiversity-Assessments for creating a scientific base for the adaptation strategy' is one of the promising national initiatives that assess the impact of weather extremes on ecosystem services comprehensively (Hungarian Academy of Science 2007).

\section{General discussion}

We obtained general information about the biophysical aspects of ecosystem services from the literature and open interviews. The interviews provided essential information on the social aspects of ecosystem services, that is, the recognition of how local people perceive and use (or ignore) these services. Finally, we also assessed the 'external' aspect of ecosystem services, that is, the influence of policy measures and weather extremes, which occur in the whole river basin and not only in the study regions. This information was mostly collected from the literature and partly from interviews. In general, more quantitative and representative data were available about provisioning services (e.g. yield statistics) than about regulating services (e.g. statistics about flood frequency were available, but not ones about pest numbers). For cultural services, we obtained mainly qualitative information, primarily from interviews. The different character of the services and the stronger national and local interest in provisioning (and some regulating) services than in (other) regulating and cultural services justify the need for different approaches. Whereas food provision, water regulation and natural hazard regulation proved to be the bestdocumented, medicinal resources, pest control, waste purification and aesthetic values were generally poorly documented. Nutrient supply and erosion control services were excluded from the study due to the insufficiency of information available. Our approach emphasizes the different properties of the three influencing factors, the lack of prior research and the limited availability of quantified data.

Our qualitative assessment enables the comparison and synthesis of a wide range of data and various ecosystems and ecosystem services, some of which have been more studied than others. This type of regional assessment tackles specific problems and can provide information for the management of a certain area (Nelson et al. 2009; Peterson et al. 2003). Many earlier ecosystem service studies target a specific land cover/land use (e.g. Turner et al. 2000 on wetlands and Guo et al. 2001 on forests) or a specific ecosystem service (e.g. Kremen et al. 2004 on pollination and Guo et al. 2000 on water flow regulation). Other studies focus only on a given factor and its effect on ecosystems and their services (e.g. Nelson et al. 2009 on land use and management, Thuiller et al. 2005 on climate change and Willemen et al. 2010 on policy measures). We used various sources to develop a more integrated qualitative approach assessing multiple factors and multiple ecosystem services in the Tisza River Basin. We suggest that by following an ecosystem services approach and explicitly considering the role of different factors in the provision of ecosystem services, more targeted and location-specific policies and management approaches can be formulated. These should sustain long-term ecosystem service supplies. Our analysis supports recent scientific discourses, which emphasize the increasing need to understand both the relationships between multiple ecosystem services and the mechanisms behind these relationships, as well as mapping to analyse and communicate these relationships in a spatially explicit way (Bennett et al. 2009; Nelson et al. 2009; Raudsepp-Hearne et al. 2010).

\section{Conclusion}

We assessed how ecosystem services are represented in policy measures, recognized by people and affected by weather extremes, all of which are reflected in land and water management. Our research focused on the Hungarian and Romanian regions of the Tisza River Basin. The analysis showed a complex relationship between these three factors and the provision of ecosystem services. Our research also shows that the ecosystem service concept is currently poorly integrated in the scientific literature, ecosystem management and decision-making in both Hungary and Romania.

Overall, the supply of ecosystem services is similar in the two countries. However, our results also show differences between services and countries. The two regions share similar environmental conditions, but variations in ecosystem services recognition and supply may emerge from the different social, political and institutional settings. In Romania, the provisioning services of food and raw materials are more recognized, while in Hungary, the regulating and cultural services (mainly recreation and ecotourism) are better appreciated. We attribute this difference to the greater direct reliance on provisioning services in Romania and to the more wide-spread knowledge on the role of floodplains in water regulation and the stronger need to address water-related risk in Hungary.

We conclude that the ecosystem service approach can contribute to a better understanding of the role and influence of the different factors involved on ecosystem service 
supply in the Tisza River Basin. We suggest that the supply of ecosystem services could be enhanced and diversified by better integrating them into policy and management plans. Although our analysis was mainly qualitative, it shows that local people's recognition and regional and national policy perspectives are important aspects of ecosystem service analysis. Information about people's specific relationships with their surroundings, for example, can be used to establish better, location-specific management plans.

Acknowledgments This research was part of and financed by the EU research project ADAM (Project no. 018476-GOCE). The authors would like to commemorate the late Zsuzsanna Flachner (RISSAC) for her expertise in the field and support in our research. Furthermore, we would like to thank all interviewees for sharing their experience of the management of the case study regions investigated in the Tisza River Basin. The manuscript was reviewed by Wolfgang Cramer and two anonymous reviewers. Their comments and suggestions are highly appreciated.

Open Access This article is distributed under the terms of the Creative Commons Attribution License which permits any use, distribution, and reproduction in any medium, provided the original author(s) and the source are credited.

\section{References}

Badica P (2007) Interview with Roxana Bojariu. National Administration of Meteorology. Romania Libera. http://www.romanialibera.ro/

Bellon T (2004) Living together with nature-farming on the river flats in the valley of the Tisza. Acta Etnographica Hungarica 49:243-256

Benedek P (2005) Pest-plant relations in the light of possible climate change. 'Agro-21' Brochures 43:39-44

Bennett EM, Peterson GD, Gordon LJ (2009) Understanding relationships among multiple ecosystem services. Ecol Lett 12(12):1394-1404

Bihari Z, Lakatos M, Szalay S, Szentimrei T (2005) Some characteristics of the climate in Hungary since 1901. Hungarian Meteorological Service, Budapest

Binning C, Cork S, Parry R, Shelton D (2001) Natural assets: an inventory of ecosystem goods and services in the Goulburn Broken catchment. CSIRO, Canberra

Blujdea V (2005) Study regarding the observation of the impact of the climate change on the forests Annals of the Forest Research and Management Institute 48. Institute for Forest Research and Management, Bucharest

Burkhard B, Kroll F, Müller F, Windhorst W (2009) Landscapes 'capacities to provide ecosystem services-a concept for land-cover based assessments. Landsc Online 15:1-22

Chiriac D, Geicu A, Humă C, Bleahu A (2005) Socio-economic effects of drought on the quality of life of human communities in Romania. Calitatea vieţii 16:1-20

Ciulache S, Ionac N (1995) Atmospheric risk phenomena. Editura Ştiinţifică, Bucharest

Crişuri Water Directorate (2006) Annual synthesis regarding water quality in the Crişuri watershed (Sinteza anuală privind calitatea apelor din bazinul hidrografic Crişuri). Crişuri Water Directorate, Oradea (Romania)

Daily GC, Polasky S, Goldstein J, Kareiva PM, Mooney HA, Pejchar L, Ricketts TH, Salzman J, Shallenberger R (2009) Ecosystem services in decision making: time to deliver. Front Ecol Environ 7(1):21-28. doi:10.1890/080025

De Groot R (2006) Function-analysis and valuation as a tool to assess land use conflicts in planning for sustainable, multi-functional landscapes. Landsc Urban Plan 75(3-4):175-186

De Groot RS, Wilson MA, Boumans RMJ (2002) A typology for the classification, description and valuation of ecosystem functions, goods and services. Ecol Econ 41(3):393-408

De Groot R, Fisher B, Christie M, Aronson J, Braat L, Haines-Young R, Gowdy J, Maltby E, Neuville A, Polasky S, Portela R, Ring I (2010a) Integrating the ecological and economic dimensions in biodiversity and ecosystem service valuation. In: Kumar P (ed) The economics of ecosystems and biodiversity: ecological and economic foundations. Earthscan, London

De Groot RS, Alkemade R, Braat L, Hein L, Willemen L (2010b) Challenges in integrating the concept of ecosystem services and values in landscape planning, management and decision making. Ecol Complexity 7(3):260-272

Dimache G (2007) General presentation of the wet areas proposed for the sectors Tinca and Sudrigiu on the Crişul Negru River. National Institute of Research and Development for Environment Protection (ICIM), Bucharest

EEA (2007) Climate change on water adaptation issues, vol 2. European Environmental Agency, Copenhagen

European INTERREG Neighbourhood Programme of Hungary and Ukraine (2006) Concept study. Development of a complex investment plan for flood control, water management and the revitalization of the "Borzsa and Bereg" river basin. FETIKÖVIZIG, RISSAC, Nyíregyháza-Uzhorod

Folke C, Carpenter S, Walker B, Scheffer M, Elmqvist T, Gunderson L, Holling CS (2004) Regime shifts, resilience, and biodiversity in ecosystem management. Annu Rev Ecol Evol Syst 35:557-581

Government of Hungary (2007a) Environment and Energy Operational Programme, Budapest

Government of Hungary (2007b) New Hungary Rural Development Programme, Budapest

Government of Hungary (2007c) The North Great Plain Operational Programme, Budapest

Government of Romania (2005) Standard form Natura 2000. Ministry of Environment ans Sustainable Development, Bucharest

Government of Romania (2007a) National Rural Development Programme, Bucharest

Government of Romania (2007b) Regional Operational Programme, Bucharest

Government of Romania (2007c) Sectoral Operational Programme for Environment, Bucharest

Groza A, Barbu R, Stanciu E, Hulea D, Banaduc D (2006) Natura 2000 in the new EU member states-one year after accession: status report for new and candidate member states (questionnaire Romania). Ministry of Environment and Sustainable Development, WWF-Danube Carpathian Programme, Romanian Ornithological Society, Ecotur Sibiu NGO

Guo ZW, Xiao XM, Li DM (2000) An assessment of ecosystem services: water flow regulation and hydroelectric power production. Ecol Appl 10(3):925-936

Guo Z, Xiao X, Gan Y, Zheng Y (2001) Ecosystem functions, services and their values - a case study in Xingshan County of China. Ecol Econ 38(1):141-154

Hein L (2010) Economics and ecosystems. Efficiency, sustainability and equity in ecosystem management. Edward Elgar Publishing Limited, Cheltenham

Hein L, Van Koppen K, de Groot RS, van Ierland EC (2006) Spatial scales, stakeholders and the valuation of ecosystem services. Ecol Econ 57(2):209-228 
Hungarian Academy of Science (2006a) National effects of global climate change and answers to give-summary report. Ministry of Environment and Water, Budapest

Hungarian Academy of Science (2006b) National effects of global climate change and answers to give-summary report (A globális klímaváltozással összefüggő hazai hatások és erre adandó válaszok). Ministry of Environment and Water Budapest

Hungarian Academy of Science (2007) Climate change and biodiversity-assessments for creating a scientific base for the adaptation strategy. Ministry of Environment and Water, Budapest

Hungarian Meteorological Service, Eötvös Loránd University (2006) Climate scenarios for the national climate change strategy. Ministry of Environment and Water, Budapest

Jolánkai G, Gulyás P, Németh J, and Kavrán V (2004) Ecological characterisation of the Tisza River and its oxbows, Annex 9. Water Resources Research Centre (VITUKI), Budapest

Kosoy N, Martinez-Tuna M, Muradian R, Martinez-Alier J (2007) Payments for environmental services in watersheds: Insights from a comparative study of three cases in Central America. Ecol Econ 61(2-3):446-455

Kremen C, Williams NM, Bugg RL, Fay GP, Thorp RW (2004) The area requirements of an ecosystem service: crop pollination by native bee communities in California. Ecol Lett 7:1109-1119

Liu J, Li S, Ouyang Z, Tam C, Chen X (2008) Ecological and socioeconomic effects of China's policies for ecosystem services. Proc Natl Acad Sci 105(28):9477-9482. doi:10.1073/pnas. 0706436105

MA (2005) Ecosystems and human well-being: synthesis report. Island Press, Washington

Minca EL, Petz K, Werners S (2008) An ecosystem services approach in the Tisza River Basin. Tiscia 36:35-40

Ministry of Water and Environment (2008) Hungarian national climate strategy. Ministry of Water and Environment, Hungary

Molnár G, Karakai T, Kajner P (2007) Possible financing sources of the floodplain management between 2007-2013. European INTERREG Neighbourhood Programme of Hungary and Ukraine. Bokartisz, Environmental Management and Landscape Rehabilitation Public Utility Company of the Bodrogköz, Karcsa

Nelson E, Mendoza G, Regetz J, Polasky S, Tallis H, Cameron D, Chan KMA, Daily GC, Goldstein J, Kareiva PM, Lonsdorf E, Naidoo R, Ricketts TH, Shaw M (2009) Modeling multiple ecosystem services, biodiversity conservation, commodity production, and tradeoffs at landscape scales. Front Ecol Environ 7(1):4-11. doi:10.1890/080023

Niemeijer D, de Groot RS (2008) A conceptual framework for selecting environmental indicator sets. Ecol Indic 8(1):14-25. doi:10.1016/j.ecolind.2006.11.012

Peterson GD, Beard TD Jr, Beisner BE, Bennett EM, Carpenter SR, Cumming G, Dent CL, Havlicek TD (2003) Assessing future ecosystem services: a case study of the Northern Highlands Lake District, Wisconsin. Conserv Ecol 7(3):1

Raudsepp-Hearne C, Peterson GD, Bennett EM (2010) Ecosystem service bundles for analyzing tradeoffs in diverse landscapes. Proc Natl Acad Sci 107(11):5242-5247. doi:10.1073/pnas. 0907284107

Schröter D, Cramer W, Leemans R, Prentice IC, Araújo MB, Arnell NW, Bondeau A, Bugmann H, Carter TR, Gracia CA, de la Vega-Leinert AC, Erhard M, Ewert F, Glendining M, House JI, Kankaanpää S, Klein RJT, Lavorel S, Lindner M, Metzger MJ, Meyer J, Mitchell TD, Reginster I, Rounsevell M, Sabaté S, Sitch S, Smith B, Smith J, Smith P, Sykes MT, Thonicke K, Thuiller W, Tuck G, Zaehle S, Zierl B (2005) Ecosystem service supply and vulnerability to global change in Europe. Science 310(5752):1333-1337. doi:10.1126/science.1115233

Sheil D, Puri R, Wan M, Basuki I, Heist Mv, Liswanti N, Rukmiyati, Rachmatika I, Samsoedin I (2006) Recognizing Local People's Priorities for Tropical Forest Biodiversity. AMBIO J Hum Environ 35(1):17-24. doi:10.1579/0044-7447-35.1.17

Slovak Hydrometeorological Institute (2003) The Tisza River Project - real-life scale integrated catchment models for supporting water- and environmental management decisions. Budapest, Hungary. EVK1-CT-2001-00099

Stancioiu PT, Abrudan IV, Dutca I (2010) The Natura 2000 Ecological network and forests in Romania: implications on management and administration. Int For Rev 12(1):106-113

Szász G (2005) The variability of climate and the yield variation of field crops. 'Agro-21' Brochures 38:59-77

Thuiller W, Lavorel S, Araújo MB, Sykes MT, Prentice IC (2005) Climate change threats to plant diversity in Europe. Proc Natl Acad Sci 102(23):8245-8250

Turner RK, Van den Bergh JCJM, Soderqvist T, Barendregt A, Van der Straaten J, Maltby E, Van Ierlan EC (2000) Ecologicaleconomic analysis of wetlands: scientific integration for management and policy. Ecol Econ 36:7-21

Upper-Tisza Environment and Water Authority (2007) Gulács-Jánd protected areas report. FETIKOVIZIG, Nyíregyháza

Vermes L (2006) The national drought strategy. 'Agro-21' Brochures 48:30-33

Werners SE, Flachner Z, Matczak P, Falaleeva M, Leemans R (2009) Exploring earth system governance: a case study of floodplain management along the Tisza river in Hungary. Glob Environ Change 19(4):503-511

Willemen L, Hein L, Verburg PH (2010) Evaluating the impact of regional development policies on future landscape services. Ecol Econ 69(11):2244-2254

World Resources Institute, United Nations Development Programme, United Nations Environment Programme, World Bank (2000) World resources 2000-2001: people and ecosystems-the fraying web of life. WRI, Washington 